\title{
Progress in Gas and Electric Welding.
}

$\mathrm{T}^{\mathrm{H}}$ HE art of welding iron has been practised for thousands of years, and specimens of ancient welded work, such as chains, are to be found in many museums. Such work was, of necessity, done in the smithy, with a fire, anvil, and hammer. To-day, thanks to the use of gas and electricity, welding can be done wherever it is required, and even bridges, buildings, and ships can be welded instead of riveted. The progress in the art has indeed been remarkable, and only last March the American Society for Testing Materials had a symposium on welding.

In Great Britain the subject is the special study of the Institution of Welding Engineers, at a meeting of which, held at Birmingham on Nov. 13, a paper was read on "Boilerworks' Practice", by Messrs. E. W. Thompson and A. Jeavons. The flues and furnaces of Lancashire and Cornish boilers were arnong the first parts to be welded and much work of a similar nature is now done by the aid of water-gas welding machines. An interesting development on the Continent and in the United States is the use of welded drums for water-tube boilers. Such drums cannot, at present, be used in Great Britain owing to the regulations of the insurance companies. The cost of a riveted drum may be $£ 40-£ 50$ a ton, a forged drum $£ 60-£ 150$ a ton according to size, while a welded drum might cost less than $£ 40$ a ton. If electric welding is used for pressure vessels a special X-ray radiograph machine is desirable, so that any slag inclusions, gas spots, or incomplete penetration can be detected.

Like so many other industries, that of electric welding traces its history back to Faraday's discoveries, and in the first number of Electric Welding, the new house journal of Messrs. The Quasi-Arc Company Limited, is an article on the Faraday Centenary by Mr. H. M. Sayers. Much of the issue, however, is devoted to the use of electric welding for ships. Descriptions are given of the electrically welded lighter $A C .1320$, built for the Inland Waterways Section of the Royal Engineers in 1918, the Fullagar, now the Shean, the first completely welded sea-going ship, and two partly welded Japanese vessels. The Fullagar was built by Messrs. Cammell Laird and Co. in 1920. During her service she has been aground several times, but is still in good condition. She is motor driven and is now engaged in the cement trade in British Columbia.

Another aspect of the subject is presented by the pamphlet "Welding of Structures", by Mr. V. A. Prince, published by the Association of Engineering and Shipbuilding Draughtsmen. Welding, says Mr. Prince, ranks eighth on the list of industries of the United States. As usual, when new processes are applied to production work, it is difficult for the draughtsman to obtain trustworthy data. Mr. Prince's pamphlet contains notes on the methods of electric welding, the plant required, the training of welders, types of welds, and on factors of safety. $\mathrm{He}$ then gives designs for a crane girder, a roof truss, and a welded stanchion base. Tests made by the United States Bureau of Standards show that welded stanchion bases are practically as strong as the heaviest types of riveted bases. Welded work will often show a considerable saving in weight and cost over riveted work. The various gas welding methods are: water-gas, oxy-acetylene, oxy-coal gas, oxyhydrogen, and a combined gas and electrical method known as the atomic hydrogen process.

Much research is being carried out in Great Britain, America, Germany, Switzerland, and elsewhere, and methods are becoming standardised and rules formulated. One of the great advantages of using welding for buildings being erected in cities is the absence of noise, such as accompanies riveting.

\section{Lecture Experiments on the Migration of Ions and the Passivity of Iron.}

TTHE following details of demonstrations successfully made throughout the recent Faraday Exhibition at the Albert Hall may be of use to those who wish to show the migration of ions and the periodic passivity of iron on the lecture table.

\section{Migration of IONS.}

The migration of ions under the influence of an electric current is generally demonstrated by passing a current through an agar-agar gel having in it an electrolyte with a coloured ion, such as copper sulphate, and contained in a glass tube bent into the form of a $\mathrm{U}$. The drawback of this method is that, in order to obtain a good colour, a considerable quantity of electrolyte is necessary, and this increases the conductivity of the gel to such an extent that when more than a small voltage is applied the current produces sufficient heat to melt or in some cases even to boil the gel. Now, as the rate of migration of the ions is proportional to the potential gradient, this small voltage will cause only a slow movement of the coloured boundary, and it is generally found that at least an hour is necessary for any change in position to be observed.

To overcome this difficulty and to make the demonstration more suitable for a lecture experiment, the conditions must be somewhat modified. The electrolyte used is a very small quantity of sodium sulphate, and to render the moving boundary visible an acid alkali indicator, bromo-cresol purple, is also added.
The $U$-tube is made in the form of a lantern slide, so that the image of the moving boundary can be projected on to a screen. The slide is made by cutting a lantern plate along the dotted lines as shown in Fig. 1 and removing the shaded portions. This plate is then cemented between two other plates, using Canada balsam or Coates's cement, thus forming a $U$-tube in which each limb is $\frac{1}{4}$ in. wide and the limbs are $\frac{1}{2}$ in. apart. The thickness of the U-tube is, of course, the thickness of the glass plate, about $1 / 20 \mathrm{in.}$. It is advantageous to cement another plate to one side of the slide, inserting two narrow strips of glass between this plate and the slide. This pro-

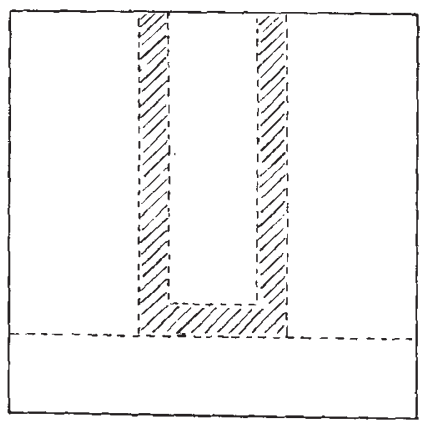

FIG. 1 . vides an air space between the actual slide and the lamp of the lantern, thus reducing the heating effect from this source.

The U-tube is nearly filled with the following solution: Water $100 \mathrm{ml}$, agar-agar 0.8-1.0 gm., sodium sulphate $0.1 \mathrm{gm}$. approximately, and sufficient bromo-cresol purple solution to give a good red colour.

No. 3249, Vou. 129] 
When the gel has set, a few drops of very dilute sodium sulphate solution are placed on top of it in each limb and a potential of 200 volts d.c. is applied across the $U$-tube, connexion being made by means of platinum wires dipping into the sodium sulphate solution. A purple colour will then move down one limb and a yellow colour down the other, and this movement can be readily observed on the screen, expecially if the screen has horizontal lines ruled across it. When the images of the moving boundaries have moved out of the field of view, the current can be reversed so that a yellow colour will move down one limb, obliterating the purple, while the yellow in the other limb will be obliterated by purple.

J. L. BUCHAN.

\section{Periodic Passivity of Iron.}

A convenient and effective method for the demonstration of the periodic electrochemical passivity of iron is shown diagrammatically in Fig. 2. $B$ is a two-

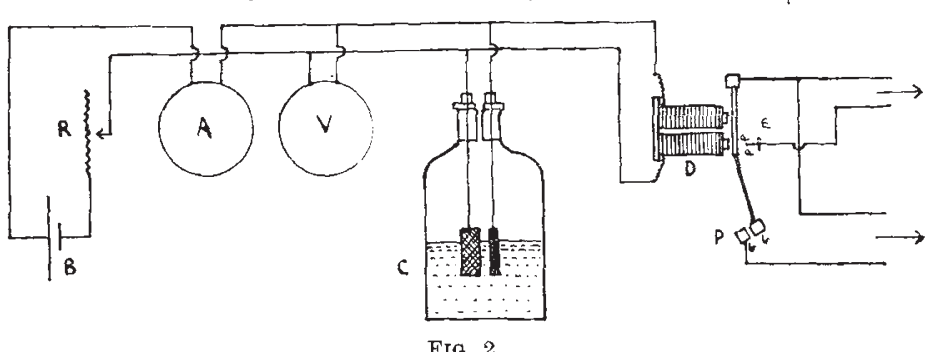

FIG. 2.

volt accumulator; $A$ an ammeter reading up to 3 amp.; $V$ a voltmeter reading up to 3 volts ; $R$ a variable resistance of $16 \mathrm{ohms} ; D$ an electro-magnetic relay having two sets of contacts, $a, a$, and $b, b$, such that one of two circuits is completed according to the position of the moving arm. The coils of the relay take approximately $0.3 \mathrm{amp}$. $C$, the cell, is a $6-\mathrm{oz}$. bottle fitted with an ebonite top carrying two brass rods and having two vent holes. A platinum gauze is used for the cathode and an iron plate ( $1 \frac{1}{4}$ in. $\times \frac{1}{2}$ in. $\times \frac{1}{8}$ in.) for the anode, these being attached to the brass rods with set screws. $85 \mathrm{ml}$. of sulphuric acid $(35 \mathrm{ml}$. conc. $\mathrm{H}_{2} \mathrm{SO}_{4}$ to $100 \mathrm{ml}$. water) are placed in the bottle; the anode is then half immersed. The entire cell is maintained at a temperature of $45^{\circ}-50^{\circ} \mathrm{C}$. in a water bath.

Periodicity may be started as follows:

The iron anode is dipped in nitric acid (1:2) and allowed to dissolve freely for 10 seconds. It is then removed from the acid, washed, dried, and attached to its appropriate brass rod. The circuit having been completed, the resistance is adjusted to a point when on immersion of the electrodes in the sulphuric acid the current attains a value of $2 \cdot 2$ amp. This is obtained as soon as the acid has overcome the passive film due to the treatment with nitric acid. Thereupon the electrodes are removed from the warm sulphuric acid and immersed in cold saturated solution of ferrous sulphate rendered decidedly acid with sulphuric acid with the current still running; the passive condition now appears. This state is maintained for 1 or 2 minutess, and finally the electrodes are returned to the warm cell. Periodicity will begin and, under the existing conditions, will be maintained until the anode is dissolved.

An adjusting screw $E$ attached to the moving arm of the relay by a spring is provided to overcome the magnetic effect produced by the coils when the anode is in the active condition; that is to say, when the amperage is $2 \cdot 2$ and the voltage 0.7 . Further, the contact pillar $P$ must be so placed that when the amperage drops to 0.3 and the voltage rises to 1.8 (the passive state) the moving arm does not touch the magnets.

In either of the conditions, passivity or activity, one of the relay circuits is completed, whereby it is possible to light up coloured lamps in an alternating manner. J. G. N. Gaskin.

\section{Madras Fisheries.*}

TN the Administrative Report of the Madras Fisheries Department for the year ending June 30, 1930 , the director, Dr. Sundara Raj, records a general improvement in almost every quarter, especially with regard to research work, in spite of the fact that the fishing season on the west coast was exceptionally bad. The Department has now at its disposal the full-sized steam trawler Lady Goschen, which has been remodelled and equipped with a laboratory and a whole-time biologist for research on board, and two well-furnished biological stations on shore at Calicut and Krusadai Island.

The chief aim and immediate work in connexion with the trawler is exploratory, as at present practically nothing is known of the contents and character of the seas outside the ten-mile limit. A survey will be made of the deeper water fishing grounds and the determination of the kinds and quantities of the marketable fish available at different seasons and depths together with investigations into the invertebrates, including plankton. Such research naturally involves the use of the best-known methods of capture, and drift and seine nets were on order with a motor boat for working the Danish seine net. At first the systematic survey will be limited to the

* Madras Tisheries Department. Administrative Report for the Year 1929-30 by Dr. B. Sundara Raj, Director of Fisheries. Report No. 1 of 1931. Malras Fisheries Bulletin, Vol. 25; 1931. Report on a Systematic Survey of Deep-sea Fishing Grounds by S.T. Lady Goschen, 1927-28. Report No. 3 of 1929, Madras Fisheries Bulletin, Vol. $23 ; 1931$.

No. 3249, VOL. 129] offshore belt to 100 fathoms, up to which the local fishermen with slightly improved boats and nets may be persuaded to extend their operations. The systematic survey of the deep-sea fishing grounds by the Lady Goschen began in 1927. During the period between Oct. 31, 1927, and March 10, 1928, she explored the extensive trawling ground within the 100-fathom line which lies to the west, south, and east of Cape Comorin, known as the Cape Comorin Bank. Details of the hauls are given in three appendices to Report No. 3, including the most important fishes and invertebrates, and three charts of the area investigated.

Researches on the Madras oyster show that it flourishes in low salinities and that the freshets in rivers, instead of damaging oyster beds as was formerly supposed, apparently provide the most favourable conditions for spawning and development of the local oyster. A field study of the extensive natural beds at Gokulapalli showed three zones; the first, which is dry for part of the summer except for a few hours during high tide, and on which are only small and yearling oysters and where much spat falls; the second, washed frequently by daily tides and exposed for much less time, where only small oysters grow as their feeding hours are limited, the size increasing with the depth, but where a good deal of spat also falls; lastly, a third zone well below the low-tide level where the oysters are large and the spat scarcely settles at all. It is 